九州大学学術情報リポジトリ

Kyushu University Institutional Repository

\title{
TRIBE CLYTINI OF OKINAWA PREFECTURE (COLEOPTERA : CERAMBYCIDAE)
}

Makihara, Hiroshi

https://doi.org/10.5109/2398

出版情報: ESAKIA. 14, pp.149-173，1979-11-15. Entomological Laboratory，Faculty of Agriculture, Kyushu University バージョン :

権利関係 : 


\title{
TRIBE CLYTINI OF OKINAWA PREFECTURE (COLEOPTERA : CERAMBYCIDAE)*
}

\author{
H IROShi MAKIHARA \\ Entomological Laboratory, Faculty of Agriculture \\ Kyushu University, Fukuoka 812, Japan
}

\begin{abstract}
Seventeen species of longicorn beetles belonging to the tribe Clytini of Okinawa Prefecture are discussed. Two new species, Xylotrechus albolatifasciatus and Perissustsutsumii are described. Clytus tinsunshi Ohbayashi et Ohbayashi, 1965 is treated as a synonym of Xylotrechus chujoi ishigakianus (Ohbayashi, 1964), which is a new combination. Perissus ishigakianus Ohbayashi, 1964 is treated as a subspecies of Xylotrechus chujoi Hayashi, 1960.
\end{abstract}

In the present paper, the results of my recent studies on the tribe Clytini of Okinawa Prefecture are presented. Seventeen species are discussed. Two new species, Xylotrechus albolatifasciatus and Perissus tsutsumii are described. Perissus ishigakianus Ohbayashi, which was described from Ishigaki Island is considered to be a subspecies of Xylotrechus chujoi Hayashi described from Okinawa Island. Clytus tinsunshi Ohbayashi et Ohbayashi from Ishigaki Island is synoymized with a new combination, Xylotrechus chujoi ishigakianus (Ohbayashi). Comments are also made on the geographic variation of some species.

I wish to express my sincere gratitude to Professor Y. Hirashima and Associate Professor K. Morimoto of Kyushu University for their continuous kind guidance. My thanks are due to Professor S. Azuma of University of the Ryukyus, Mr. N. Ohbayashi of Kanagawa Experiment Station and Messrs. T. Tsutsumi, K. Nicho, H. Fujita, M. Fukamachi and T. Yano for the donation or the loan of the valuable specimens as well as the type specimens for my present study. I am also grateful to Mr. K. Yogi of Ishigaki City for his kind help to my collecting trips to Ishigaki Island.

\section{Tribe Chytini}

Mulsant, 1839, Hist. nat. col. France, Longicornes, p.70.(Clytaires)

* Contribution from the Entomological Laboratory, Faculty of Agriculture, Kyushu University, Fukuoka (Ser. 3, No. 71). 
Thomson, 1860, Classif. cerambyc., p. 214. (Clytitae)

Thomson, 1864, Syst. cerambyc., p. 184. (Clytitae)

Gahan, 1906, Fauna Brit. India, Col. 1: 239.

Matsushita, 1933, J. Fac. Agr. Hokkaido Imp. Univ., 34(2): 264.

Mitono, 1941, Bull School Agr. For, Taihoku Imp. Univ., 2: 75.

Gressitt, 1951, Longicornia, 2: 230.

Kojima et Hayashi, 1969, Ins. Life Japan, 1: 74.

Gressitt et Rondon, 1970, Pac. Ins. Mon., 24: 194.

Nakane, 1976, Kontyû to Shizen, 11(11): 12.

\section{Key to genera of Clytini of O kinawa Prefecture}

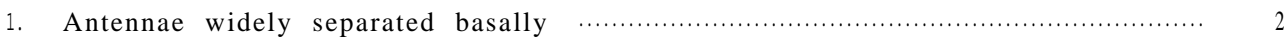

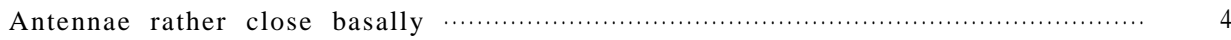

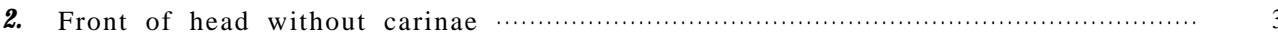

- Front of head with a V-shaped or branching carinae; lateral sides of frons carinate; antennae short ................................................... Xylotrechus

3. First hind tarsal segment less than 2.5 times as long as $2+3$; antennae short,

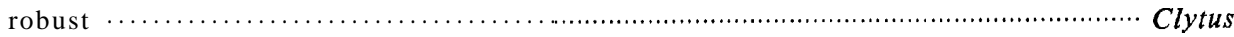

First hind tarsal segment more than 2.5 times as long as $2+3$; antennae rather

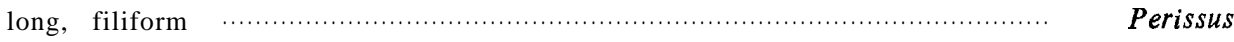

4. Antennae without spines at apices of segments 5 Antennae with spines at apices of segments 3-4

3. Antenna1 segment 3 longer than 1; antennae not extremely close basally ..... Rhaphuma

- Antennal segment 3 not longer than 1; antennae extremely close basally... Chlorophorus

\section{Genus Xylotrechus Chevrolat}

Xylotrechus Chevrolat, 1860, Ann. Soc. Ent. France ser. 3, 8: 465; Thomson, 1864, Syst. cerambyc., p. 424; Pascoe, 1869, Trans. Ent. Soc. London, ser. 3, 3: 606; Gahan, 1906, Fauna Brit. India, Col., 1: 241; Matsushita, 1933, J. Fac. Agr. Hokkaido Imp. Univ., 34(2): 265 ; Mitono, 1941, Bull. School Agr. For. Taihoku Imp. Univ., 2: 79; Gressitt, 1951, Longicornia, 2 : 231; Linsley, 1964, Univ. California Pub. Ent., 22 : 104; Samuelson et Gressitt, 1965, Pac. Ins., 7(1): 74; Kojima et Hayashi, 1969, Ins. Life Japan, 1: 74; Gressitt et Rondon, 1970, Pac. Ins. Mon., 24 : 194; Nakane, 1976, Kontyû to Shizen, 11(11): 13 .

\section{K EY TO THE OKINAWAN SPECIES OF Xylotrechus*}

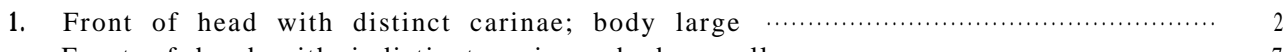

- Front of head with indistinct carinae; body small ................................. 7

2. Pronotum without a red band; abdominal sternites with white or yellow bands $\cdots \cdots \cdot 3$

- Pronotum with a red, an orange and a black bands; elytra with oblique orange and blackish brown bands on basal $2 / 3$, with orange and narrow blackish brown bands on apical 1/3; abdominal sternites with orange bands ; body length $15-25 \mathrm{~mm}$

Xylotrechus chinensis (Chevrolat)

3. Front of head with a distinct V-shaped carina, pronotum without small whitish yellow spots ; mid and hind femora and tarsi black or brown on basal halves $\ldots . . . . .4$

* Some species closely related to the Okinawan species are also included. 

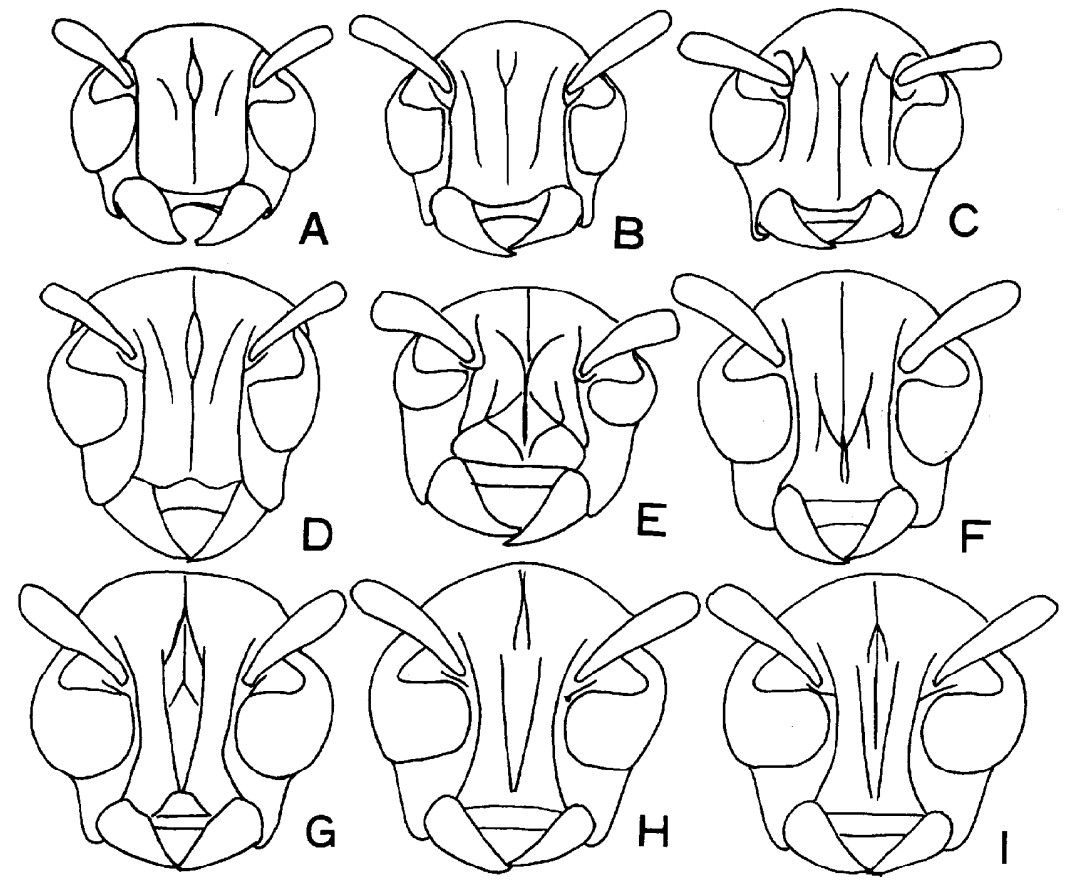

Fig. 1. Heads of Xylotrechus spp. A : albolatifasciatus sp. nov. B ; reductomaculatus C : lautus. $\mathrm{D}$ : chujoi ishigakianus. $\mathrm{E}$ : chinensis. $\mathrm{F}$ : grayii. $\mathrm{G}$ : atronotatus angulithorax. $\mathrm{H}$ : atronotatus generosus. I: atronotatus atronotatus.

Front of head with a pair of parallel, not clearly V-shaped carina; pronotum with ten whitish yellow spots; elytra with a narrow zig-zag white line on basal half, and an oblique narrow white one on apical half; mid and hind femora and tarsi red except apical $1 / 3$; body length $9.0-16.5 \mathrm{~mm}$

Xylotrechus grayii (White)

Pronotum angulate at side; front of head with 2 V-shaped and A-shaped median carinae, fused together

Pronotum rounded at side; front of head with $2 \mathrm{~V}$-shaped and A-shaped median carinae, open above

Pronotum angulate at side on basal $1 / 3$; body length $8-16 \mathrm{~mm}$

Xylotrechus atronotatus angulithorax Gressitt from Amami-Ôshima I. and Tokunoshima I. (Figs. 11 and $\mathbf{1 5} \mathrm{A}$ )

Pronotum angulate at side on basal 2/5; body length $10-16 \mathrm{~mm}$....................

Xylotrechus atronotatus angulithorax Gressitt from Okinawa I.

Pronotum with black markings at middle and sides; elytra with broad pale bands ; body length $10.5-18.0 \mathrm{~mm}$

Xylotrechus atronotatus atronotatus Pic from Taiwan (Figs. 11, 14 and 15 D)

Pronotum with black markings on median and lateral portions, confused below and above; elytra with narrow pale bands; body length $8-18 \mathrm{~mm}$

Xvlotrechus atronotatus generosus Gressitt from Ishigaki I. and Iriomote I.

Elytra with one or two oblique bands and apical markings not clear $\ldots \ldots \ldots \ldots \ldots \ldots \ldots . . . . . .6$

Elytra with two markings, $\mathrm{X}$-shaped on basal $1 / 3$ and $\mathrm{T}$-shaped on apical $1 / 3$,

clear on female and not clear in male ; body length $6.5-10.5 \mathrm{~mm} \ldots \ldots \ldots \ldots \ldots \ldots$ 
8. Abdominal sternites 3-4 with white pubescent bands

- Abdominal sternites 3-6 with white pubescence ; elytra with two oblique bands; body length $7-8 \mathrm{~mm}$... Xylotrechus lautus Matsushita from West Japan and Yakushima I.

9. Body with golden green pubescence; elytra rather short, relative measurement of width to length 2.35 in male; legs long, relative measurement of body

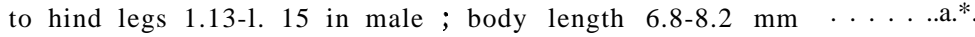

Xylotrechus chujoi chujoi Hayashi

- Body with whitish yellow pubescence; elytra rather long, relative measurement of width to length 2.40-2.63 in male; legs short, relative measurement of body to hind legs 1.02-1. 12 in male; body length 6.3-10.5 mm .............. Xylotrechus chujoi ishigakianus (Ohbayashi)

10. Elytra with an oblique band and two spots on base and basal 1/3; pronotum with white markings on base; body length $6.5-8.0 \mathrm{~mm}$

Xylotrechus reductomaculatus Hayashi from Nakanoshima I. and Amami-Ôshima I.

- Elytra with two oblique bands, a narrow one and a wide one; pronotum with small white markings on base not clear; body length 5.6-8.0 mm

Xylotrechus albolatifasciatus sp. nov.

\section{Xylotrechus albolatifasciatus sp. nov.}

(Figs. 1 A. 2, 3, 6, 7 and 10 A, B D, G)

Body black; antennae and legs brown; disc of elytral markings yellow.

Head closely punctured, with median long and lateral short carinae, covered with white or yellow pubescence, and with long oblique whitish yellow hairs on sides of frons and lateral and ventral sides; eyes large, relative length of inferior eye lobes to gena 1.4; antennae short, relative length to body 0.50-o. 51 (male), 0.46-o. 48 (female), relative length of each segment as $12.8: 7.2: 12.8: 10.5: 11.2: 8.7: 8.3: 7.3: 7.2: 6.2: 7.8$ (male), $14.1: 7.5:$ $1.0: 9.8: 11.2: 8.2: 8.0: 7.2: 7.0: 6.4: 8.5$ (female) ; long oblique white hairs on segment 1 and ventral sides of segments $2-5$, short oblique ones on segments 6-11 sparsely, whitish yellow pubsecence on segments 1-5 sparsely and on 6-11 densely.

Pronotum circular, closely punctured, with long oblique white hairs sparsely on lateral sides, with golden yellow and white pubescence densely on lateral sides and sparsely on another parts.

Scutellum semicircular, with white or golden green pubescence densely on apex.

Elytra parallel at basal $9 / 10$, relative measurement of width to length 2.42.6 (male), 2.5-2.7 (female) ; apices nearly roundly truncate, with two white pubescent bands, a narrow one extending obliquely backward from suture behind scutellum to basal $1 / 3$, and a wide one parallel to the narrow one near middle, apices with white patch of pubescence broad in male, narrow in female, and another parts with white or golden yellow pubescence.

Legs long; femora and tibiae with white suberect hairs sparsely; mid and hind femora with short oblique white hairs on ventral sides. 


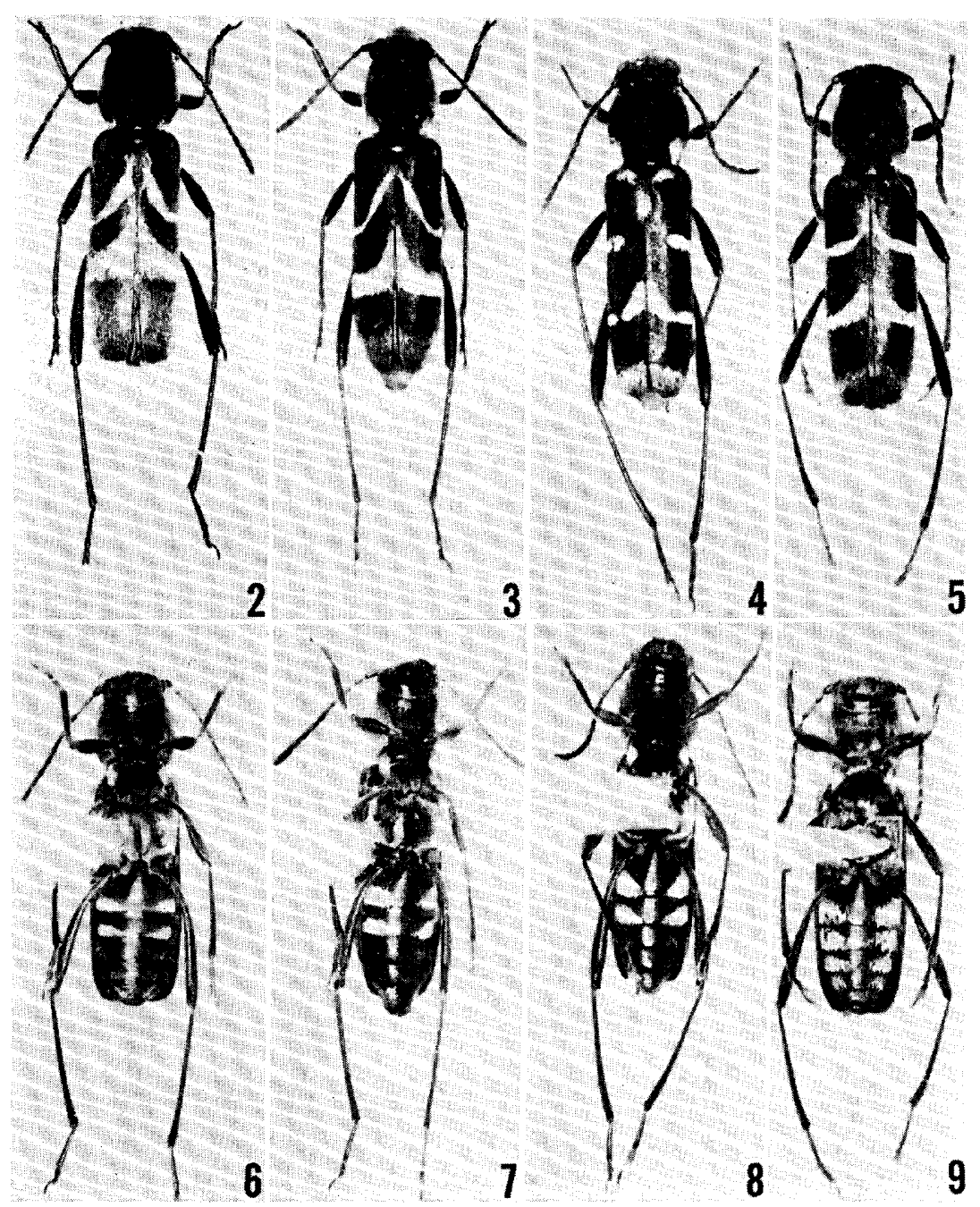

Figs. 2-9. Xylotrechus spp. 2-5: Dorsal view, 6-9: ventral view. 2, 3, 6 \& 7: albolatifasciatus sp. nov. 4 \& 8: reductomaculatus. 5 \& 9 :lautus.

Ventral side with white pubescence on mesepisternum, metepimeron and apices of abdominal sternites 3-4 densely, another parts with pubescence not dense.

Male genitalia robust; median lobe with median struts rather long and slightly curved; tegumen with roof and without basal piece ; lateral lobes wide and short, with three long setae on apices and short setae all over.

Length : 7.6-8.6 mm (male), 5.4-7.2 $\mathrm{mm}$ (female).

Distribution : Okinawa I.

Type material: Holotype $\precsim$ (Type No. 2166, Kyushu Univ.), Oku, Oki- 
nawa I., emerged from a decayed vine, Elaegnus glabra Thunb., Elaegnaceae, 8. XI. 1975, T. Yano leg, Paratypes §, Yona, Okinawa I., 17. iii, 1974, M. Fukamachi leg. ; 우, Oku, Okinawa I., 29. iii,‘ 1975, H. Fujita leg. ;우, same locality as above, emerged from a decayed tree, Acacia confusa Merrill, Leguminosae, 3. ii. 1975, T. Tsutsumi leg. ; 오, same locality and collector as above,

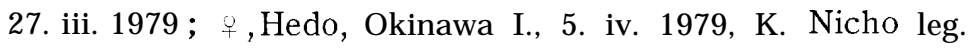

Type Depository: The holotype is preserved in the collection of the Entomological Laboratory, Faculty of Agriculture, Kyushu University.

DiAgnosis: This new species is related to X. lautus Matsushita from West Japan and Yakushima I., but separable from it by the following points : Elytral white bands broad, elytral apices subrounded; and antenna1 segment 5 relatively short. The new species is also related to $\mathrm{X}$. reductomaculatus Hayashi from Nakanoshima I., Amami-Ôshima I. and Tokunoshima I., but is separable from it as follows : Elytral white bands complete and broad; and parameres of male genitalia broad (Figs. $1 \mathrm{~A}, \mathrm{~B}, \mathrm{C}$ and Z-10).
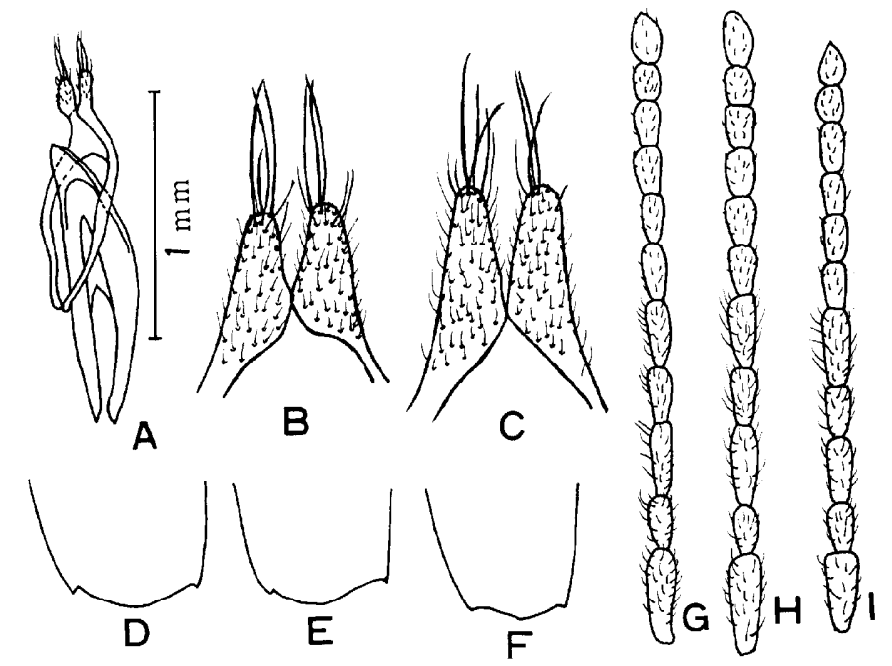

Fig. 10. Xylotrechus spp. A : Male genitalia of albolatifasciatus. B \& C: Parameres (B : albolatifasciatus. C:reductomaculatus). D-F : Elytral apices (D : albolatifasciatus. H: reductomaculatus. F: lautus). G-I : Antenna (G : albolatifasciatus. H : reductomaculatus. I : laütus).

\section{Xylotrechus atronotatus angulithorax Gressitt}

(Figs. $1 \mathrm{G}, 11$ and $15 \mathrm{~B}$ )

Xylotrechus angulithorax Gressitt, 1934, Pan-Pac. Ent., 9: 165; Hayashi, 1960, Ent. Rev. Japan, 11(1): 23, textfig. 3, pl. 4, figs. 1, 3, 4; 1962, ibid., 14(1): 10; Kojima et al., 1965, Res. Rep. Kôchi Univ. 14, Nat. Sci., 2(9): 14; Kojima et Hayashi, 1969, Ins. Life Japan, 1: 75, pl. 23, fig. 5; Chûjô, 1972, Mem. Fac.Educ. Kagawa Univ., 2(208): 15; Azuma et al., 1976, Bull, Coll. Agr. Univ. Ryukyus, 23: 144; Nakane, 1976, Kontyh to Shizen, 11 (12) $: 5$. 
Xylotrechus basalis angulithorax var. generosus: Miwa, 1935, Trans. Kansai Ent. Soc., 6: 25, pl. 4 , fig. 14.

Xylotrechus atronotatus angulithorax: Mitono, 1941, Bull. School Agr. For. Taihoku Imp. Univ., 2: 91, pl. 7, figs. 6, 7 (part) ; Gressitt, 1951. Phil. J. Sci., 79(2): 213.

Xylotrechus (s. str.) generosus angulithorax : Samuelson et Gressitt, 1965, Pac. Ins., 7(1): 75.

SPeCimens EXAmined : Okinawa I.: 1 ex. Yona, 12. vi. 1970, H. Makihara leg. ; 2 exs., same locality and collector as above, 15. vi. 1970; 1 ex., Hyakuna, 18. vi. 1970, same collector as above; 1 ex., Mt. Yonaha, 12. vii. 1977, same collector as above; 1 ex., same locality and collector as above, 20. v. 1978.

Distribution : Okinawa I.

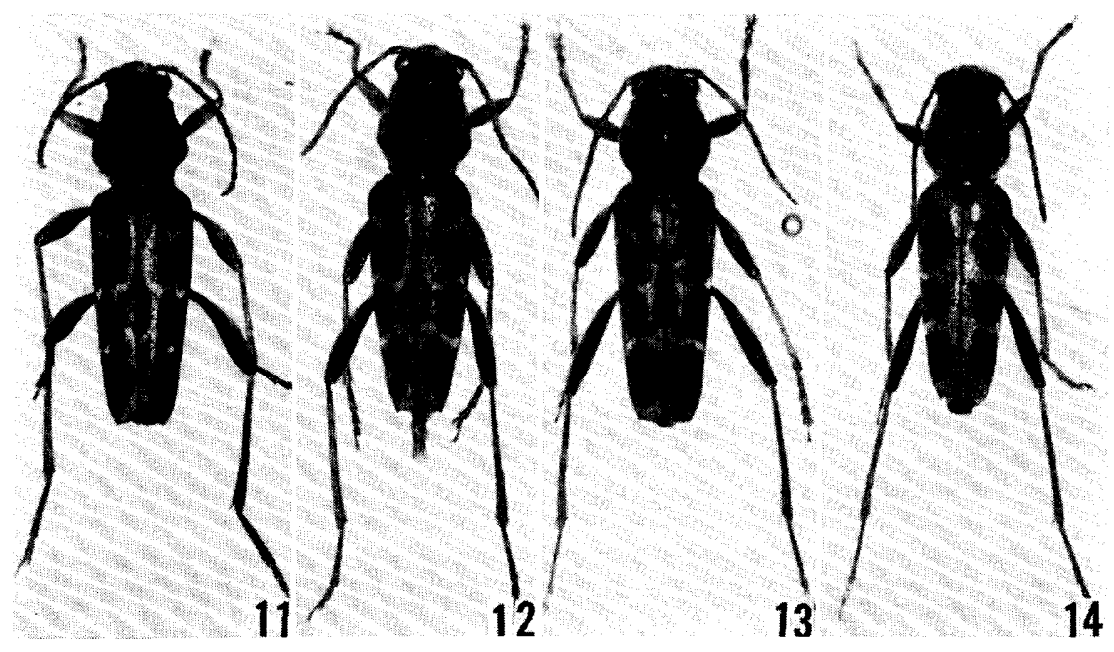

Figs. 11-14. Xylotrechus atronotatus subspp. 11: angulithorax from Amami-Ôshima I. 12: angulithorax from Okinawa I. 13: generosus from Iriomote I. 14: atronotatus from Taiwan.

Xylotrechus atronotatus generosus Matsushita

(Figs. $1 \mathrm{H}, 13$ and $15 \mathrm{C}$ )

Xylotrechus generosus Matsushita, 1933, J. Fac. Agr. Hokkaido Imp. Univ., 34: 270, pl. 11, fig. 1.

Xylotrechus basalis: Miwa, 1933, Trans. Nat. Hist. Soc. Formosa, 23: 13.

Xylotrechus basalis angulithorax: Mitono, 1940, Cat. Col. Japonic., 8: 106.

Xylotrechus atronotatus angulithorax: Mitono, 1941, Bull. School Agr. For. Taihoku Imp. Univ., 2: 91, pl. 7: figs. 6, 7 (part).

Xylotrechus (s. str.) atronotatus generosus : Gressitt, 1951, Phil. J. Sci., 79(2): 213.

Xylotrechus atronotatus generosus: Kojima et al., 1965, Res. Rep. Kôchi Univ., 14, Nat. Sci. 2 (9): 14

Xylotrechus (s. s tr.) generosus generosus: Samuelson et Gressitt, 1965, Pac. Ins., 7(1): 75.

Xylotrechus atronotatus generosus: Hayashi, 1969, Ins. Life Japan, 1: 75, pl. 23, fig. 4; Chûjô, 1970, Mem. Fac.Educ. Kagawa Univ., 2(192): 50; 1971, ibid., 2(202):29; Nakane, 1976, Kontyû to Shizen, 11(12): 5; Yano, 1977, Elytra, 5(1): 21. 


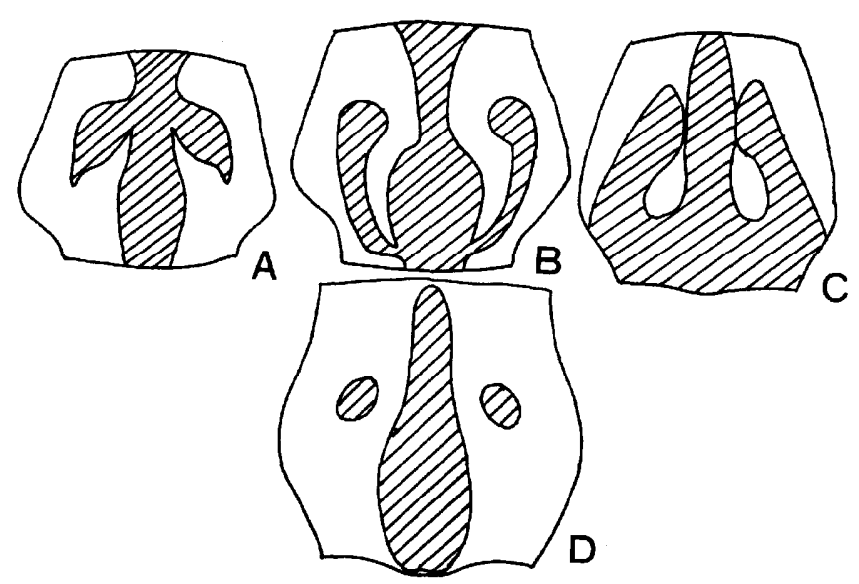

Fig. 15. Prono turn of Xylotrechus atronotatus subspp. A: angulithorax from Amami-Ôshima I. B: angulithorax from Okinawa I. C: generosus from Iriomote I. D: atronotatus from Taiwan

Specimens EX A M INE D: Ishigaki I. : 1 ex., Mt. Banna, 4. vii. 1970, H. Makihara leg. ; 1 ex. Yonehara, 24. vi. 1972, M. Hayashi leg.; 2 exs., Botanical Garden, Banna, 10. vi. 1974, H. Makihara leg. Iriomote I.: 2 exs. Mt. Goza, 15-21. iv. 1969, H. Makihara leg.; 13 exs., Nakara River, 25-28. vi. 1970, same collector as above; 4 exs., Funaura, 13. iv. 1979, same collector as above.

Distribution: Ishigaki I., Iriomote I., Taketomi I., Kohama I. and Hateruma I.

REMARKs: X. atronotatus shows a cline from Taiwan to Amami-Ôshima I. in regard to the angulation of the lateral sides of the pronotum which is intensified from south to north.

\section{Xylotrechus chinensis (Chevrolat)}

(Figs. 1 E and 24)

Clytus chinensis Chevrolat, 1852, Rev. Mag. Zool., (2) 4: 416.

Xylotrechus sinensis: Sakaguchi, 1927. Prov. Lists Ins. Okinawa.

Xylotrechus chinensis: Yashiro, 1927, Okinawa Sugar Exp. Sta. Bull., 1: 8; Kojima et $\mathbb{a} 1$. , 1965, Res. Rep. Kôchi Univ. 14, Nat. Sci. 2(9); 84; Kojima et Hayashi, 1969, Ins. Life Japan, 1: 75, pl. 23. fig. 1; Nakane, 1976, Konty û to Shizen. 11(12): 2.

Xylotrechus (s. str.) chinensis: Gressitt, 1951, Phil. J. Sci., 79(2): 213; Samuelson et Gressitt, 1965, Pac. Ins., 7(1): 74.

Specimens examined : Okinawa I. : 1 ex. Shuri, 13. v. 1976, T. Tsutsumi leg. Distribution: Hokkaido, Honshu, Shikoku, Kyushu, Sado I., Miyake I., Kôzu I., Mikura I., Awashima I., Awajishima I., Tsushima I., Amami-Ôshima I., Tokunoshima I. and Okinawa I. ; Korea, China and Taiwan. 

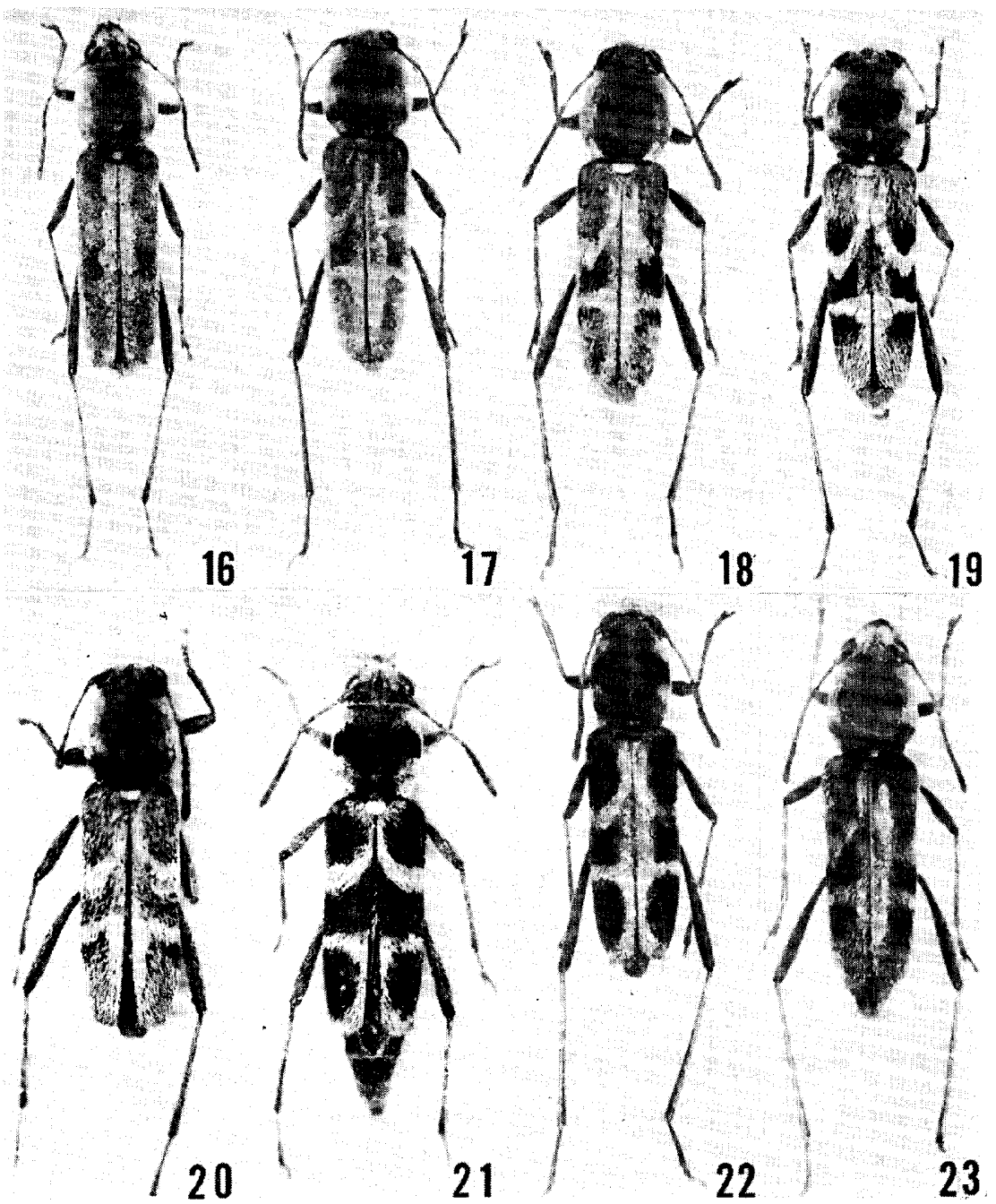

Figs. 16-23. Xylotrechus chujoi subspp. 16-20: ishigakianus, male (20:Perissus ishigakianus, holotype, misregarded as a female). 21 \& 22: ishigakianus, female (21: Clytus tinsunshi, holotype). 23 : chujoi, male.

\section{Xylotrechus chujoi chujoi Hayashi}

(Fig. 23)

Xylotrechus chujoi Hayashi, 1960, Ent. Rev. Japan, 11(1): 24; Kojima et Hayash1, 1969, Ins.

Life Japan, 1: 75 (part) ; Nakane, 1976, Kontyû to Shizen, 11(12): 6 (part).

Male. Body black; antennae dark brown ; front of head with a median long carina, oblongly at interspace of eyes, and short carinae on lateral sides not clear; eyes large, inferior eye lobes as long as gena; antennae rather 
short, relative length to body 0.46-0. 51, relative length of each segment as $13.8: 7.1: 14.5: 11.0: 10.8: 9.1: 7.2: 6.7: 6.5: 5.7: 7.6$, with depressed white hairs and long oblique whitish yellow ones oh under sides of segments 1-5 sparsely, and segments 6-11 with suberect hairs' sparsely.

Pronotum circular, as long as broad, closely punctured, with golden green pubescence, disc with two small black spots.

Scutellum semicircular, with pubescence similar on pronotum.

Elytra parallel at basal $3 / 4$, rather long, relative measurement of width to length 2.35, apices truncate subroundly; disc with $\mathrm{X}$-shaped golden green pubescent band on basal $1 / 3$ and T-shaped similar one on apical $1 / 3$, not clear and wide.

Legs long, relative length of body to hind legs 1.13-1. 15; femora, tibiae and fore and mid tarsi with white depressed and oblique hairs sparsely, apices of hind tibiae and tarsi with brown oblique hairs, apices of tarsi with two spines on undersides.

Ventral side with depressed golden white pubescence.

Length : 6.8-8.2 $\mathrm{mm}$.

Specimens examined: Okinawa I. : la, Mt Yonaha, 13. vi. 1978, T. Takahashi leg. ;1 $\jmath^{7}$, same locality and collector as above, 21. vi. 1978.

DisTRIBUTION: Okinawa I.

Xylotrechus chujoi ishigakianus (Ohbayashi) n. comb.

(Figs. 16-22)

Perissus ishigakianus Ohbayashi, 1964, Bull. Japan Ent. Acad., 1(5): 22 ; Kojima et Hayashi, 1969, Ins. Life Japan, 1 : 79, pl. 24, fig, 11; Nakank, 1977, Kontyû to Shizen, 12(2): 3. Clytus tinsunshi Ohbayashi et Ohbayashi, 1965, Bull. Japan Ent. Acad.,2(1):3, fig. 1, new synonymy.

Xylotrechus brevicillis: Hayashi, 1963, nec Chevrolat, Ent. Rev. Japan, 16(1): 10, pl. 2, fig. 1.

Head with whitish yellow pubescence; relative length of antenna to body 0.45-o. 50 (male), 0.43-o. 48 (female), relative length of each antennal segment as $12.8: 6.6: 13.9: 11.5: 11.4: 8.9: 8.1: 7.0: 6.8: 5.8: 7.3$ (male), $14.5: 7.0:$ 13. $3: 11.8: 11.6: 8.7: 7.7: 6.7: 6.2: 5.4: 7.0$ (female).

Elytra long, relative measurement of width to length 2.40-2.63 (male), 2.47-2.64 (female), with whitish yellow pubescent bands obscure in male and narrow and clear in female.

Legs rather long, relative length of body to hind legs 1. 02-1. 12 (male), 1.05-1. 17 (female).

Ventral side with depressed whitish yellow pubescence.

Length : 6.3-10.5 mm. (male), 6. 0-7.8 mm (female).

Specimens examined: Ishigaki I.:1 1 , Takeda, 3. v. 1963, Y. Arita leg. (Perissus ishigakianus Ohbayashi, holotype ; this specimen was described as 
female) ;1 ㅇ, Mt. Omoto, 16. vii. 1964, N. Ohbayashi leg. (Clytus tinsunshi Ohbayashi et Ohbayashi, holotype) ;1우 , Botanical Garden, Banna, 20. vii. 1974, emerged from a decayed tree, H. Makihara leg.; 1 ๖, same data as above, 23. viii. 1974; $1 \precsim$, Mt. Omoto, 18. v. 1975, Y. Takahashi leg. ;1우, same locality as above, 20. v. 1975, H. Makihara leg.; $1 \widehat{\jmath}$, same locality as above, 14. vi. 1975, S. Kimoto leg. ; $1 \precsim$, same locality as above, 10. x. 1975, T. Takahashi leg. ; $2 \partial^{\lambda}, 1$ 우, same locality and collector as above, 17. iv. 1976.

\section{Distribution: Ishigaki I.}

Diagnosis: Xylotrechus chujoi Hayashi was once miscombined with Perissus and Clytus by Ohbayashi (1964) and Ohbayashi and Ohbayashi (1965), respectively. The holotype of Perissus ishigakianus Ohbayashi is a small specimen having the frontal carinae of the head weak and the first hind tarsal segments long, 2.45 times as long as $2+3$. More curiously, the holotype, which is a male, was misregarded as a female. The holotype of Clytus tinsunshi Ohbayashi et Ohbayashi is also a small specimen having the frontal carinae

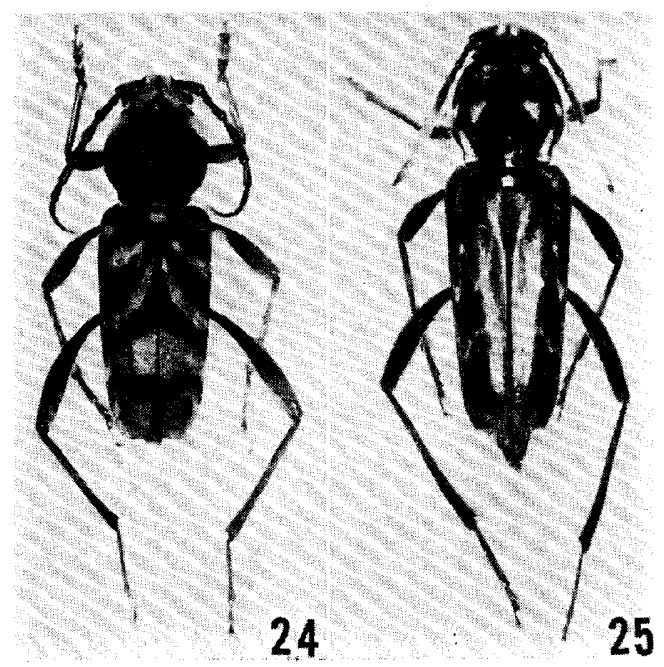

Figs. 24 \& 25. Xylotrechus spp. 24: chinensis. 25: grayii.

of the head weak, but the first hind tarsal segments shorter, 2 times as long as 2+3. In Xylotrechus chujoi Hayashi, however, the frontal carinae of the head are clear in larger specimen, and the first hind tarsal segments are variable, 1.80-2.45 times as long as the second and third hind tarsal segments taken together. Moreover, the elytral makings of the male markedly differ from those of the female in this species.

$\mathrm{X}$. chujoi ishigakianus differs from $\mathrm{X}$. chujoi chujoi from Okinawa Island in having the body with whitish yellow pubescence, the elytra long and the legs short. 


\section{Xylotrechus grayii (White)}

(Figs. $1 \mathrm{~F}$ and 25)

Clytus grayii White, 1855, Cat. Col. Brit. Mus., 8: 261, pl. 6, fig. 4.

Xylotrechus grayii: Chevrolat, 1863, Mem. Soc. Sci. Liege 18: 325; Bates, 1873, Ann. Mag. Nat. Hist. (4)12: 199; Schwarzer, 1925, Ent. Blätt., 21: 26; Kano, 1926, Trans. Nat.

Hist. Soc. Formosa, 16: 104; Matsumura, 1931, 60G0 Ill. Ins. Japan, p. 270, fig. 855; Cheo, 1935, Peking Nat. Hist. Bull., 10: 12; Pic. 1935, Ark. f.Zool., 27 A(2) : 12 ; Gressitt, 1937, Lingnan Sci. J., 16: 453; 1939, ibid., 18: 37; 1940, ibid., 19: 17; Mitono, 1941, Bull. School Agr. For. Taihoku Imp. Univ., 2: 96, pl. 6, fig. 19; Greesitt, 1951, Longicornia, 2: 243, pl. 9, fig. 8; Hayashi, 1963, Ent. Rev. Japan, 16(1): 10; Kojima et al.: 1965, Res. Rep. Kôchi Univ. 14, Nat. Sci., 2(9): 84; Kojima et Hayashi, 1969, Ins. Life Japan, 1: 77, pl. 24, fig. 1; Nakane, 1976, Kontyû to Shizen, 11(12): 146.

Specimens examined: Ishigaki I. : 1 ex. Mt. Banna, 29. iv. 1969, H. Makihara leg. ; 1 ex., same locality and collector as above, 4. vii. 1970. Iriomote I. : 3 exs., Otomi, 12. iv. 1969, H. Makihara leg. ; 1 ex., same locality and collector as above, 27. iv. 1969; 2 exs., Urauchi, 27. iii. 1978, Y. Shôno leg. Hateruma I.: 1 ex., 20. v. 1975, H. Makihara leg.

Distributon: Hokkaido, Honshu, Shikoku, Kyushu, Sado I., Hachijo I., Niijima I., Tsushima I., Yakushima I., Amami-Ôshima I., Okinawa I., Ishigaki I., Iriomote I. and Hateruma I.; Taiwan, China and Mariana Is.
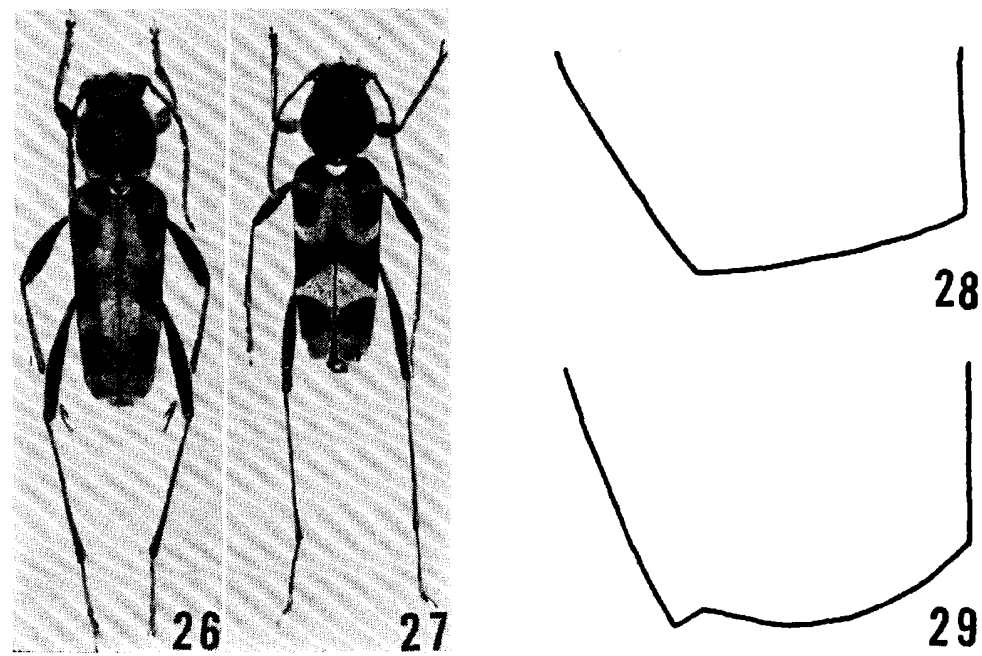

Figs. 26-29. Clytus fukienensis. 26: Amami-Ôshima I. 27: Okinawa I. 28 \& 29: Elytral apices (28: Amami-Ôshima I. 29: Okinawa I.).

\section{Genus Clytus Laicharting}

Clytus Laicharting, 1784, Verz. Tyrol. Ins., 2: 88; Mitono, 1941, Bull. School. Agr. For. Taihoku Imp. Univ., 2: 111; Gressitt, 1951, Longicornia, 2: 252; Linsley, 1964, Univ. California Pub. Ent., 22: 164; Samuelson et Gressitt, 1965, Pac. Ins., 7(1): 75; Kojima et 
Hayashi, 1969. Ins. Life, Japan, 1: 79; Gressitt et Rondon, 1970, Pac. Ins. Mon., 24: 209; Nakane, 1977, Kontyû to Shizen, 12(2):3.

\section{Clytus fukienensis Gressitt}

(Figs. 26-29)

Clytus fukienensis Gressitt, 1951, Longicornia, 2: 253, pl. 10, fig. 5; Hayashi, 1962, Ent. Rev. Japan, 14(1):11, pl. 2, fig. 7; Samuelson et Gressitt, 1965, Pac. Ins., 7(1): 76; Kojima et Hayashi, 1969, Ins. Life Japan, 1: 80, pl. 24, fig. 6; Nakane, 1977, Kontyû to Shizen, $12(2): 5$.

Specimens examined : Okinawa I. : 2 exs., Yona, 25. ii. 1977, emerged from a decayed tree, T. Tsutsumi leg.

Distribution: Amami-Ôshima I. and Okinawa I. ; China.

\section{Genus Perissus Chevrolat}

Perissus Chevrolat, 1863, Mem. Soc. Sci. Liege, 18: 262; Pascoe, 1869, Trans. Ent. Soc. London, (3) 3: 615; Gahan, 1906, Fauna Brit. India, Col., 1: 254; Matsushita, 1933, J. Fac. Agr. Hokkaido Imp. Univ., 34(2): 275; Mitono, 1941, Bull. School Agr. For. Taihoku Imp. Univ., 2: 104; Gressitt, 1951, Longicornia, 2: 264; Samuelson et Gressitt, 1965, Pac. Ins., 7(1): 76; Kojima et Hayashi, 1969, Ins. Life Japan, 1: 79; Gressitt et Rondon, 1970, Pac. Ins. Mon., 24: 210; Nakane, 1977, Kontyû to Shizen, 12(2): 3.

\section{Perissus tsutsumii sp. nov.}

(Figs. 30, 34 and $38 \mathrm{~A}, \mathrm{~B}, \mathrm{I}, \mathrm{L}$ )

Male. Body blackish brown; fore legs and antennal segments 10-11 reddish brown.

Head closely punctured, with oblique white pubescence and with long oblique white hairs on apex of frons and ventral side; eyes large, inferior eye lobes as long as gena; mouth parts with oblique golden yellow hairs; antennae rather short, relative length to body 0.64-0. 70, relative length of each segment as $11.1: 4.8: 10.6: 10.7: 12.2: 10.9: 9.7: 8.4: 7.4: 6.5: 7.8$; segments 1-5 with oblique brown hairs, segments 6-11 with short suberect brown hairs sparsely, segments 5-8 and dorsal sides of segment 9 with white pubescence densely, ventral side of segment 9 and 10-11 with reddish brown pubescence densely.

Pronotum circular, closely punctured, with two black spots on submedian portions, median portion of pronotum and the two black spots with brown pubescence, another parts with white pubescence, with erect white hairs on lateral and ventral sides sparsely.

Scutellum semicircular; apices truncate subroundly, with two weak spines; disc with two white pubescent bands, a narrow one extending obliquely backward from suture behind scutellum to basal $1 / 3$, and a wide one transverse 
at apical $1 / 3$, with white pubescence on humeri, with whitish yellow hairs on apices, another parts with blackish brown pubescence densely.

Legs very long, relative length of hind legs to body 1.4-1. 5; femora and tibiae with suberect whitish yellow hairs; tarsi with short oblique brown hairs densely, first hind tarsal segment 2.8-3.0 times as long as $2+3$.

Ventral side with white pubescence densely on mesepisternum, apical half of metepimeron, apical $1 / 3$ of metasternum and apices of abdominal sternites 3 and 4 , another parts with suberect whitish yellow hairs and brown pubescence.

Male genitalia rather slender; median lobe with long median struts; tegumen with long roof and without basal piece; lateral lobes slender, with three long setae on apices and short ones on interior.

Length : 7.8-10.5 mm.

Distribution: Okinawa I.

Type material: Holotype $\nrightarrow$ (Type No. 2167, Kyushu Univ.), Oku, Okinawa I., 28. v. 1978, T. Tsutsumi leg. Paratypes: §, Mt. Yonaha, Okinawa I., 12. vi. 1978,

K. Kawada leg.; ð, same locality as above, 13. vi. 1978, T, Takahashi leg.

TYPE DEPOSITORY: The holotype is preserved in the collection of the Entomological Laboratory, Faculty of Agriculture, Kyushu University.

Diagnosis: This new species is related to $P$. kiusiuensis Ohbayashi from West Japan including islets from Yakushima I. to Tokunoshima I. and $P$. demonacoides (Gressitt) from Taiwan, but separable from them by the following key.

\section{Key to the Oninawan species of Perissus*}

1. Apices of abdominal sternites 3-4 with white pubescent bands

- Apices of abdominal sternites 3-5 with white pubescent bands; two elytral white bands narrow; hind tarsal segment 2 slender and long; body length 8$10 \mathrm{~mm}$...........Perissus demonacoides (Gressitt) from Taiwan (Figs. 31, 35 and 38 J. M)

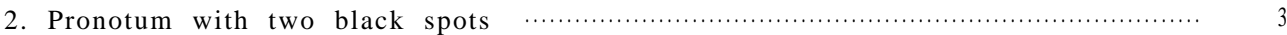
Pronotum without two black spots.................................................

3. Pronotum with white pubescent bands; elytral white pubescent bands narrow; legs reddish brown; hind tarsal segment 2 long; body length 8.5-11.5 mm..... ...............Perissus kiusiuensis Ohbayashi from Amami-Ôshima I. and Tokunoshima I. (Figs. 32, 36 and $38 \mathrm{C}, \mathrm{H}, \mathrm{K}$ )

- Pronotum with white pubescence; elytral white pubescent bands wide ; legs blackish brown (except for fore legs) ; hind tarsal segment 2 short; body length 7.8-10.5 $\mathrm{mm}$................................................... Perissus tsutsumii sp. nov,

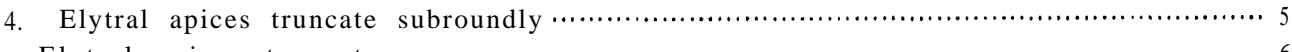

- Elytral apices truncate

5. Elytral humeri and apices with broad patch of pale pubescence; body length $8.5 \mathrm{~mm}$.......... Perissus kiusiuensis hisamatsui Ohbayashi from Hachijo I., Mikura I. and Miyake I. (Figs. 37 and $38 \mathrm{G}$ )

* Some species closely related to the Okinawan species are also included. 

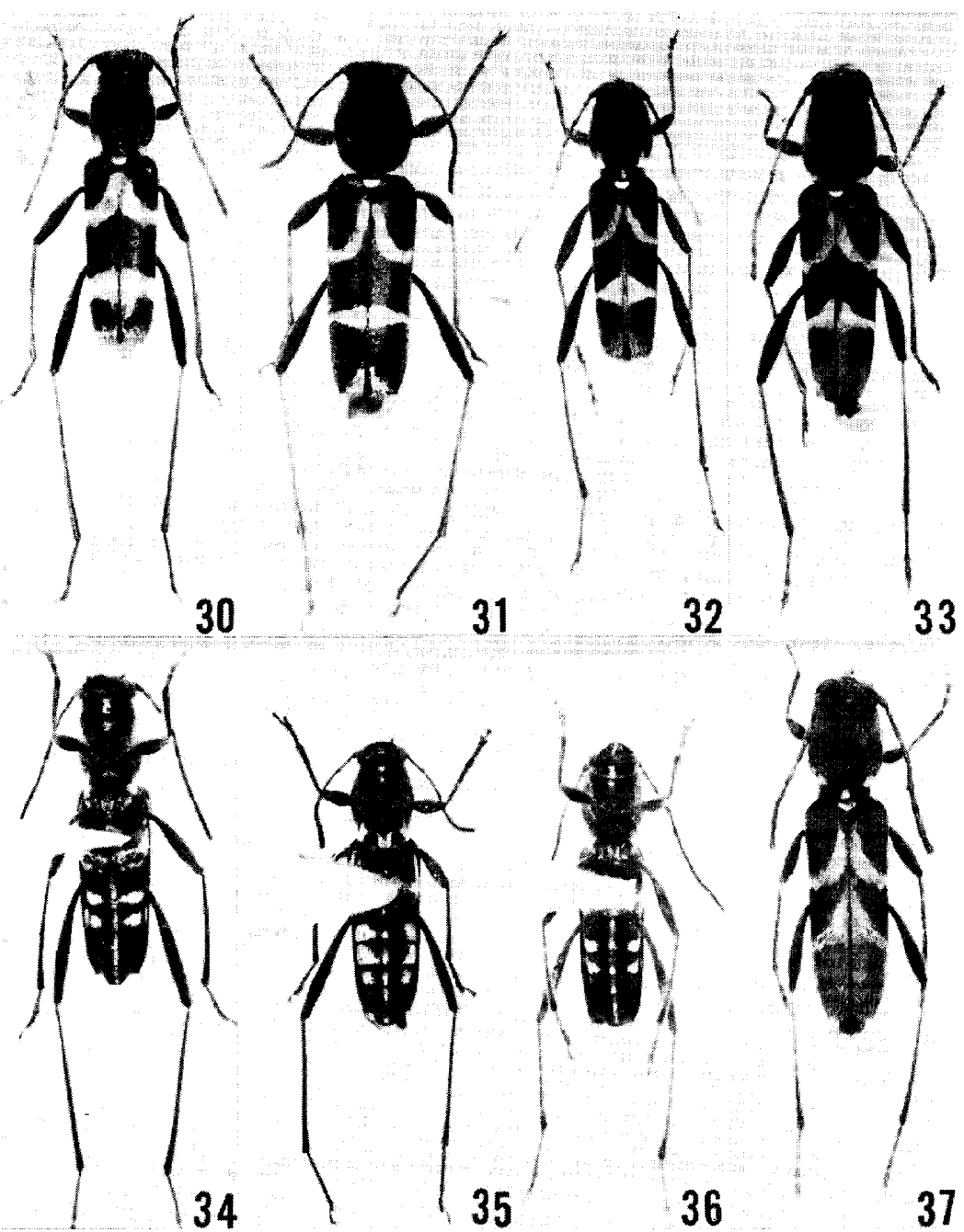

Figs. 30-37. Perissus spp. 30-33 \& 37: Dorsal views, 34-36: ventral views. 30 \& 34: tsutsumii nov. 31 \& 35: demonacoides from Taiwan. 32 \& 36: kiusiuensis from Amami-Ôshima I.

33: kiusiuensis from Yakushima I. 37: kiusiuensis hisamatsui from Mikura I.

Elytral humeri and apices with patch of whitish yellow pubescence not wide; body length 7-10 mm …..... Perissus kiusiuensis Ohbayashi from West Japan (Fig. 38 D) Elytral humeri and apices with patch of pale pubescence rather wide ; elytral apices with spines not developed; body length $9.5-11.0 \mathrm{~mm}$

Perissus kiusiuensis Ohbayashi from Yakushima I. (Figs. 33 and 38E) Elytra with patch of pale pubescence wide; elytral apices with spines rather developed; body length 6-7 $\mathrm{mm}$

Perissus kiusiuensis Ohbayashi* from Nakanoshima I. (Fig. 38 F)

* The pattern of geographic variation of Perissus kiusiuensis Ohbayashi from Kyushu to Nakanoshima I. is distinctive in being the pubescence on the elytra getting denser and the elytral spines more developed from north to south. 


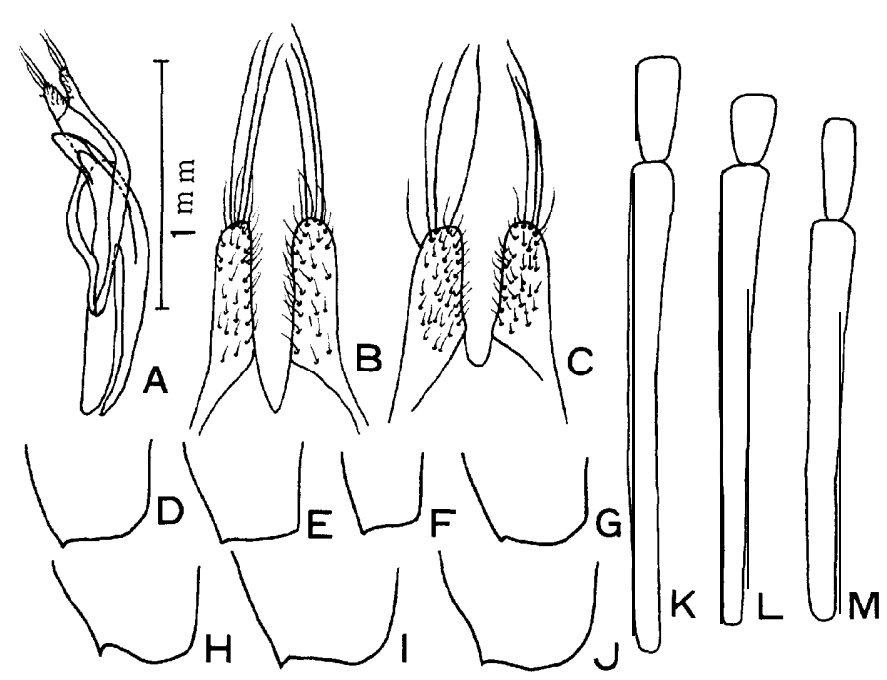

Fig. 38. Perissus spp. A : Male genitalia of tsutsumii. B \& C: Parameres (B: tsutsumii. C: kiusiuensis from Amami-Ôshima I.). D-J: Elytral apices (D: kiusiuensis from Kyushu. E. kiusiuensis from Yakushima I. F: kiusiuensis from Nakanoshima I. G: kiusiuensis hisamatsui from Mikura I. H: kiusiuensis from Amami-Ôshima I. I: tsutsumii. J: demonacoides from Taiwan). K-M: Hind tarsal segments 2 \& 3 (K: kiusiuensis from Amami-Ôshima I. $\mathrm{L}$ : tsutsumii. $\mathrm{M}$ : demonacoides).

\section{Genus Chlorophorus Chevrolat}

Chlorophorus Chevrolat, 1863, Mem. Soc. Sci. Liege, 18: 290; Gressitt, 1951, Longicornia, 2: 270; Samuelson et Gressitt, 1965, Pac. Ins., 7(1): 76: Kojima et Hayashi, 1969, Ins. Life Japan, 1: 82; Gressitt et Rondon, 1970, Pac. Ins. Mon. 24: 218; Nakane, 1977, Kontyû to Shizen, $12(3): 6$.

Caloclytus: Gahan, 1906, Fauna Brit. India, Col. 1: 260.

\section{Key to THE OKINAWAN SPECIES of Chlorophorus}

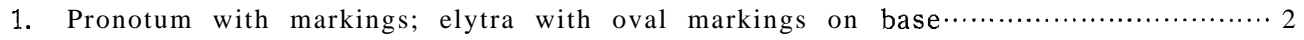

- Pronotum without markings ; elytra without oval markings on base; body with dense pale green pubescence; body length $9.12 \mathrm{~mm}$...... Chlorophorus muscosus (Bates)

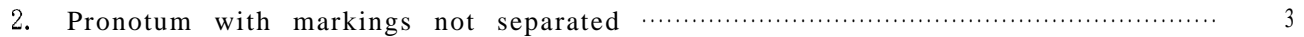

- Pronotum with markings separated …............................................ 4

3. Pronotum weakly constricted at base, with a transverse united marking; body with dense orange yellow or orange red and dark brown pubescence; elytral apices truncate subroundly ; body length $12-18 \mathrm{~mm}$

Chlorophorus quinquefasciatus (Castelnau et Gory)

- Pronotum strongly constricted at base, with a marking united at apex: head and pronotum with pale green pubescence; elytra with yellow and brown pubescence ; elytral apices truncate obliquely ; body length $9-15 \mathrm{~mm}$

Chlorophorus annularis (Fabricius)

4. Elytral median marking united transversely, complete; body with dense orange yellow pubescence ; elytral markings brown ; body length 10-16 m m

Chlorophorus aritai (Ohbayashi) 
Elytral median markings separated by suture; body with dirty yellow pubes-

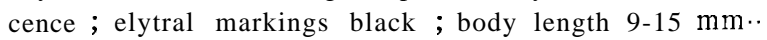

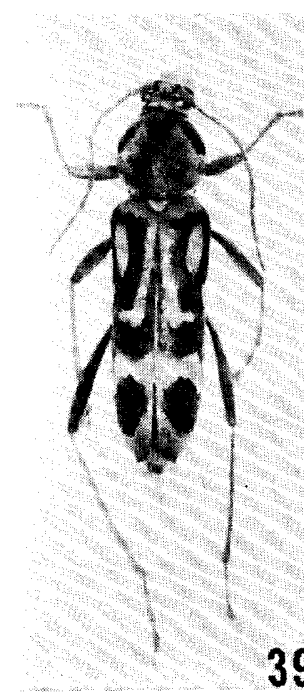

Figs. 39-42.
Chlorophorus spp. ...........................

\section{Chlorophorus annularis (Fabricius)}

(Figs. 39 and 43A)

Callidium annulare Fabricius, 1787, Mant. Ins., 1: 156.

Clytus annularis: Fabricius, 1801, Syst. Eleuth, 2: 352.

Callidium bidens Weber, 1801, Obs. Ent., p. 90.

Caloclytus annularis: Gahan, 1906, Fauna Brit. India, Col., 1: 261.

Chlorophorus annularis: Miwa, 1933, Trans. Nat. Hist. Soc. Formosa, 23: 13; Matsushita, 1933, J. Fac. Agr. Hokkaido Imp. Univ., 34: 280; Miwa, 1935, Trans. Kansai. Ent. Soc., 6: 25; Gressitt, 1951, Longicornia, 2: 275; 1951, Phil. J. Sci. 79(2): 214; Hayashi, 1962, Ent. Rev. Japan, 14(1) : 11; Kojima et al., 1965, Res. Rep. Kôchi Univ., 14, Nat. Sci., 2 (9) : 85; Samuelson et Gressitt, 1965, Pac. Ins. 7(1): 77; Kojima et Hayashi, 1969, Ins. Life Japan, 1: 82, pl. 25, fig. 1; Chujo, 1970, Mem. Fac.Educ. Kagawa Univ.. 2(192): 50; Gressitt et Rondon, 1970, Pac. Ins. Mon., 24: 221, fig. 35 g; Chûjô, 1972, Mem. Fac. Educ. Kagawa Univ., 2(208): 15; Azuma et al., 1976, Bull. Coll. Agr. Univ. Ryukyus, 23 : 145; Nakane, 1977, Kontyû to Shizen, $12(3): 8$.

Specimens examined: Ishigaki I. : 3 exs., Botanical Garden, Banna, $28 . \mathrm{v}$. 1974, J. Okuma leg.; 1 ex., Arakawa, 7. vi. 1974, H. Makihara leg.

Distribution: Honshu, Shikoku, Kyushu, Sado I., Awajishima I., Miyake I., Hachijo I., Tsushima I., Tanegashima I., Yakushima I., Amami-Ôshima I., Tokunoshima I., Okinoerabu I., Okinawa I., Ishigaki I., Iriomote I. and Ogasawara Is.; Korea, Taiwan, China, Burma, Thailand, Malaya, Philippine, India, 


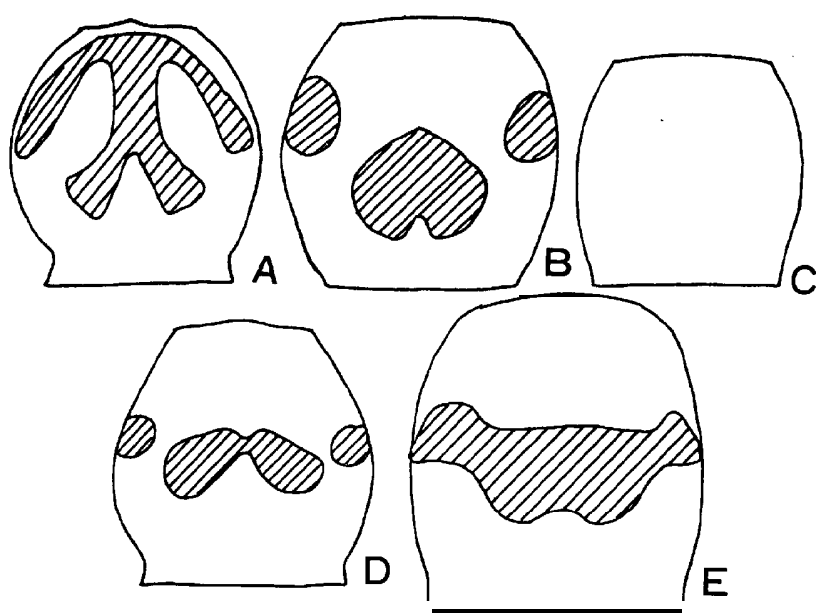

Fig. 43. Pronotum of Chlorophorus spp. A: annularis. B: aritai. C :muscosus. D : yayeyamensis. E: quinquefasciatus.

Malaysia, Cambodia, Ceylon, New Guinea, Vietnam, Hainan I., Laos, Sunda Is.

\section{Chlorophorus aritai (Ohbayashi)}

(Figs. 40 and 43B)

Rhaphuma aritai Ohbayashi, 1964, Bull. Japan Ent. Acad., 1(5): 22.

Chlorophorus aritai: Kojima et al., Res. Rep. Kochi Univ., 14, Nat. Sci. 2(9): 86; Kojima et Hayashi, 1969, Ins. Life Japan, 1: 85, pl. 26, fig. 4; Chûjô, 1970, Mem. Fac.Educ.Kagawa Univ., 2(192): 50; Nakane, 1977, Kontyû to Shizen, 12(3): 8.

Specimens examined: Miyako I. : 1 ex., Botanical Garden, Hirara, 25. v. 1974, H. Makihara leg. ; 2 exs., same locality and collector as above, 26. v. 1974; 2 exs., same locality and collector as above, 27. v. 1974; 6 exs., same locality and collector as above, 31. v. 1975; 2 exs., Uinpia, 31. v. 1975, same collector as above. Ishigaki I.: 1 ex., Mt. Banna, 20-22. vi. 1970, H. Makihara leg. ; 1 ex., Botanical Garden, Banna, 28. v. 1974, J. Okuma leg. ;4 exs., same locality as above, 14. vi. 1974, H. Makihara leg.; 7 exs., same locality and collector as above, 15. vi. 1974; 3 exs., same locality and collector as above, 16. vi. 1974; 1 ex., Mt. Omoto, 20. vi, 1974, same collector as above ; 1 ex., same locality and collector as above, 27. vi. 1974. Iriomote I. : 1 ex., Shirahama, 12. v. 1967, Y. Nomura leg.; 3 exs., Nakara River, 25-28. vi. 1970, H. Makihara leg. Yonaguni I.: 2 exs., Mt. Urabu, 9. vi. 1974, H. Makihara leg. ; 1 ex., same locality and collector as above, 13. vi. $1974 ; 2$ exs., same locality and collector as above, 22. v. 1975.

Distribution: Okinawa I., Miyako I., Ishigaki I., Iriomote I. and Yonaguni I. 


\section{Chlorophorus muscosus (Bates)}

(Figs. 41 and $43 \mathrm{C}$ )

Clytantus muscosus Bates, 1873, Ann. Mag. Nat. Hist., (4)12: 198.

Chlorophorus bifaciatus Kano, 1933, Kontyû, 7: 135.

Chlorophorus muscosus: Gressitt, 1937, Kontyû, 11: 321; Hayashi, 1962, Ent. Rev. Japan, 14(1): 11; Kojima et al., 1965, Res. Rep. Kôchi Univ., 14, Nat. Sci., 2(9): 85; Samuelson et Gressitt, 1965, Pac. Ins. 7(1): 77; Kojima et Hahashi, 1969, Ins. life Japan, 1: 83, pl. 25, fig. 7; Nakane, 1977, Kontyû to Shizen 12(3): 8 .

Rhaphuma muscosa: Ohbayashi, 1963, Fragementa Col., 3: 11.

Specimens eXamined : Okinawa I, : 1 ex., Mt. Yonaha, 20. v. 1978, H. Makihara legs ; 1 ex., Oku, 17. iv. 1979, emerged from a decayed vine, Celastrus punctatus Thunb.. Celastraceae, same collector as above; 2 exs., same locality, plant and collector as above, 29. iv. 1979.

Distridution: Honshu, Shikoku, Kyushu, Sado I., A washima I., Izu-Ôshima I., Niijima I., Miyake I., Mikura I., Hachijo I., Tsushima I., Koshiki I., Tanegashima I., Yakushima I., Kuroshima I. (Kagoshima Pref .), Kuchinoshima I., Nakanoshima I., Takarajima I., Amami-Ôshima I., Tokunoshima I., Okinoerabu I., Okinawa I. and Ogasawara Is.; Korea.

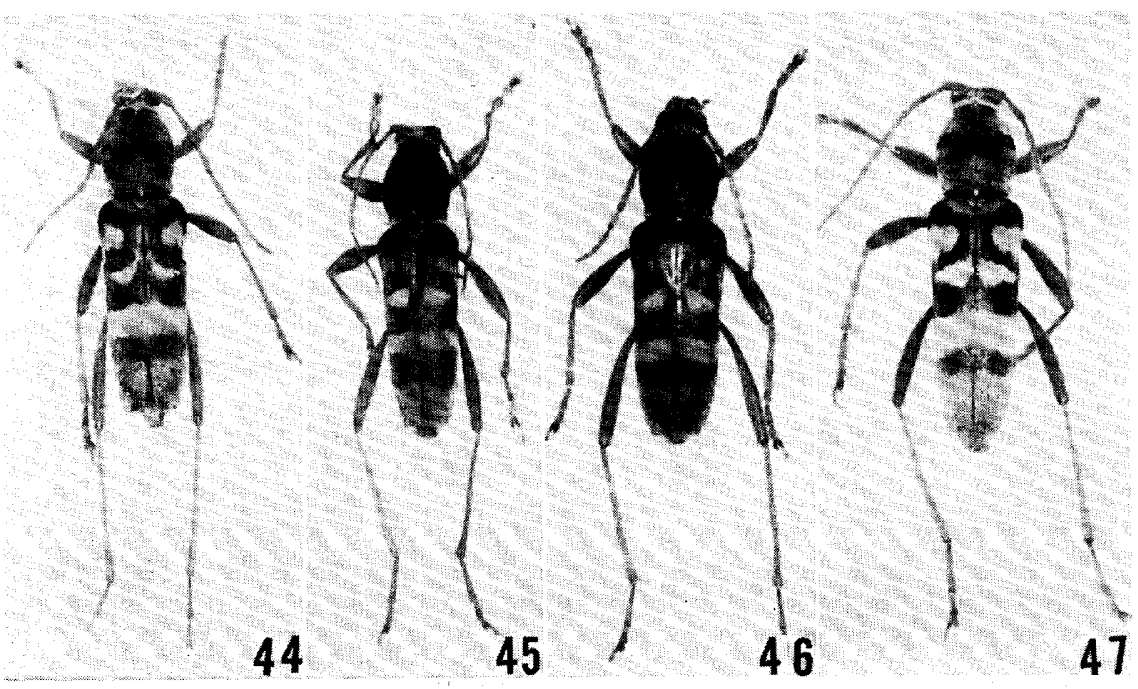

Figs. 44-47. Chlorophorus quinquefasciatus. 44: Yakushima I. 45 :Amami-Ôshima I. 46: 0 kinawa I. 47: Ishigaki I.

Chlorophorus quinquefasciatus (Castelnau et Gory)

(Figs. 43 E and 44-48)

Clytus quinquefasciatus Castelnau et Gory, 1841, Hist. Nat. Icon. Ins. Col., p. 101, pl. 19, fig. 120.

Chlorophorus quinquefaciatus : Kano, 1927, Trans. Nat. Hist. Soc. Formosa, 16: 128; Miwa, 
1933, ibid., 23 : 13; Matsushita, 1933, J. Fac. Agr. Hokkaido Imp. Univ., 34: 285; Mitono, 1940, Cat. Col. Japonic., 8: 119; Hayashi, 1962, Ent. Rev. Japan, 14(1): 11; Kojima et al., 1965, Res. Rep. Kôchi Univ., 14, Nat. Sci., 2(9): 85; Samuelson et Gressitt, 1965, Pac. Ins. 7 (1) : 77; Kojima et Hayashi, 1969, Ins. Life Japan, 1: 85, p1. 26, fig. 5; Chûjô, 1970, Mem. Fac. Educ. Kagawa Univ., 2(192): 50; Azuma et al., 1976, Bull. Coll. Agr. Univ. Ryukyus, 23: 145; Nakane ; 1977, Kontyû to Shizen,12(3): 8.

Specimens examined: Kumejima I. : 5 exs., 1. vii, 1977, H. Makihara leg. ; 5 exs., 2. vii. 1977, H. Makihara leg. Okinawa I. : 45 exs., Shuri, 11. vii. 1968, H. Makihara leg.; 3 exs., Yona, 9. viii. 1969, same collector as above; 10 exs., same locality and collector as above, E-17. 1970; 15 exs., same locality and collector as above, 15-17., vii. 1970; 15 exs., Hyakuna, 19. vii. 1970, same collector as above; 3 exs., Kudeken, 30. vi. 1974, same collector as above ; 7 exs., Shuri, 1. vii. 1974, same collector as above; 20 exs., Oku, 29-30. vi. 1976, same collector as above; 2 exs., Yona, 9. vii. 1977, same collector as above; 5 exs., Benoki, 10. vii. 1977, same collector as above ; 5 exs., Mt. Yonaha, 12. vii. 1977, same collector as above. Miyako I.: 3 exs., Botanical Garden, 24. v. 1974, H. Makihara leg.; 5 exs., same locality and collector as above, 25 . v. 1974; 8 exs. same locality and collector as above, 26. v. 1974 ; 2 exs., same locality and collector as above, 27. v. 1974; 10 exs., Uinpia, 30. v. 1975, same collector as above; 15 exs., Botanical Garden, 31. v. 1975, same collector as above. Ishigaki I.: 1 ex., Mt. Banna, 1. v. 1969, H. Makihara leg.; 30 exs., same locality and collector as above, 20-22. vi. 1970; 5 exs., Botanical Garden, Banna, 12. vi. 1974, same collector as above ; '22 exs., same locality and collector as above, 15. vi. 1974; 5 exs., same locality and collector as above, 16 . vi. 1974; 3 exs., Mt. Omoto, 20. vi. 1974, same, collector as above ; 7 exs. Botanical Garden, Banna, 27. vi. 1974, same collector as above; 5 exs., Hirakubo, 28. vi. 1974, same collector as above; 15 exs., Botanical Garden, Banna, 24. v. 1975, same collector as above; 7 exs., Arakawa, 28. v. 1975, same collector as above. Iriomote I.: 1 ex., Otomi, 24. iv. 1969, H. Makihara leg.; 24 exs., Shirahama, 2324. vi. 1970, same collector as above ; 55 exs., Nakara River, 25-28. vi. 1970, same collector as above; 15 exs., Uehara, 26. v. 1975. Yonaguni I.: 7 exs., Sonai, 6-9. vii. 1970, H. Makihara leg. ; 10 exs., Mt. Urabu, 8. vi. 1974.

Distribution: Honshu, Shikoku, Kyushu, Awajishima I., Tsushima I., Koshiki I., Tanegashima I., Yakushima I., Kuroshima I. (Kagoshima Pref.), Kuchinoerabu I., Kuchinoshima I., Nakanoshima I., Takarajima I., AmamiÔshima, I., Kikaijima I., Tokunoshima I., Okinoerabu I., Okinawa I., Kumejima I., Miyako I., Ishigaki I., Iriomote I. and Yonaguni I. : Korea and Quelpart I.

REMARKS: This species is divided into two types according to the markings, one is a wide type having the elytral oval markings, and another is a narrow type. The wide type distributes in Okinawa I. and Kumejima I., the narrow type from Yonaguni I. to Miyako I. and from Takarajima I. to 
Honshu. The intermediate type is found from Okinoerabu I. to Amami-Oshima I. (figs. 44-48).

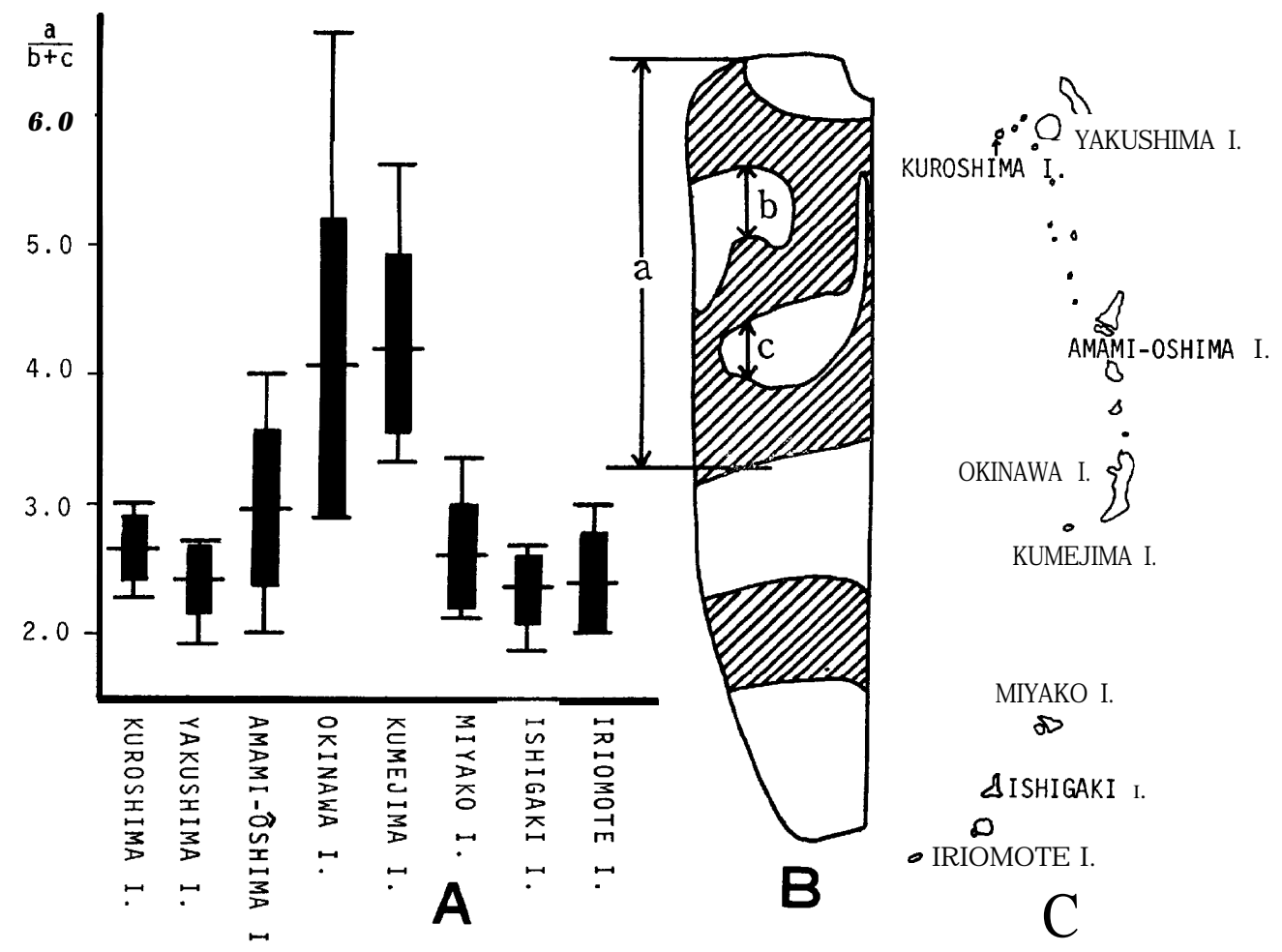

Fig. 48. Geographic variation of the elytral markings in Chlorophorus quinquefasciatus. A : Population range diagrams showing for each locality the range (thin vertical), sd (thick vertical) and the mean (horizontal); ten materials for each locality. B: Diagrammatic representation of elytral markings. C: Map of the Ryukyus.

\section{Chlorophorus yayeyamensis Kano}

(Fig. 42)

Chlorophorus yayeyamensis Kano, 1933, Kontyû,7: 137; Gressitt, 1951, Phil. J. Sci., 79(2): 215 ; Hayashi, 1962, Ent. Rev. Japan, 14(1): 11; Kojima et al., 1965, Res. Rep. Kbchi Univ., 14, Nat. Sci., 2(9): 85; Samuelson et Gressitt, 1965, Pac. Ins. 7(1): 78; Kojima et Hayashi, 1969, Ins. Life Japan, 1: 85, pl. 26, fig. 3; Chûjô, 1970, Mem. Fac.Educ. Kagawa univ., 2(192) : 50; 1971, ibid., 2(202) : 29; 1972, ibid., 2(208): 16; Makihara, 1974, Pulex, 55: 226; Ito et Moriya, 1975, Gekkan-Mushi, 50: 24; Azuma et al., 1976, Bull. Coll. Agr. Univ. Ryukyus, 23: 145; Irie et Kusama, 1976, Gekkan-Mushi, 59: 10; Nakane, 1977, Kontyû to Shizen, 12(3): 9.

Chlorophorus douei: Miwa, 1931, Dept. Agr. Govt. Res. Inst. Formosa Rep., 55: 234.

Chlorophorus dubius Matsushita, 1933, J. Fac. Agr. Hokkaido Imp. Univ., 34: 281, pl. 11, fig. $\checkmark$.

Rhaphuma yayeyamensis : Ohbayashi, 1963, Fragmenta Col., 3: 11. 
Specimens examined : Okinawa I.: 1 ex., Motobu, 19. vi. 1934, T. Esaki leg. : 1 ex., Yona, 20. vi. 1972, 0. Tadauchi leg. Miyako I. : 1 ex., Bora, 23. v. 1974, H. Makihara leg.; 2 exs., Botanical Garden, Hirara, 24. v. 1974, same collector as above; 2 exs., same locality and collector as above, 26 . v. 1974; 4 exs., same locality and collector as above, 27. v. 1974; 4 exs., same locality and collector as above, 31 v. 1975; 1 ex., Uinpia, 31. v. 1975, same collector as above. Tarama I. : 2 exs., 27. v. 1974, H. Makihara leg. Ishigaki I. : 1 ex., 22. v. 1934, C. Senaha leg.; 1 ex., Mt. Banna, 27. v. 1973, K. Ueda leg. ; 3 exs., Botanical Garden, Banna, 28. v. 1974, J. Okuma leg.; 1 ex., Arakawa, 7. vi. 1974, H. Makihara leg. ; 1 ex., same locality and collector as above, 11. vi. 1974; 1 ex., Hirakubo, 28. v. 1975, same collector as above. Iriomote I. : 1 ex., Otomi, 12. iv. 1969, H. Makihara leg. ; 1 ex., same localitv and collector as above, 23. iv. 1969; 1 ex., Nakara River, 25-28. vi. 1970, same collector as above.

Distribution: Honshu (Yamaguchi Pref.), Kyushu, Shikoku, Hachijo I., Torishima I., Tanegashima I., Yakushima I., Kuchinoerabu I., Kuchinoshima I., Nakanoshima I., Suwanose I., Takara I., Amami-Ôshima I., Tokunoshima I., Okinawa I., Miyako I., Ishigaki I., Iriomote I. and Hateruma I.; Taiwan.

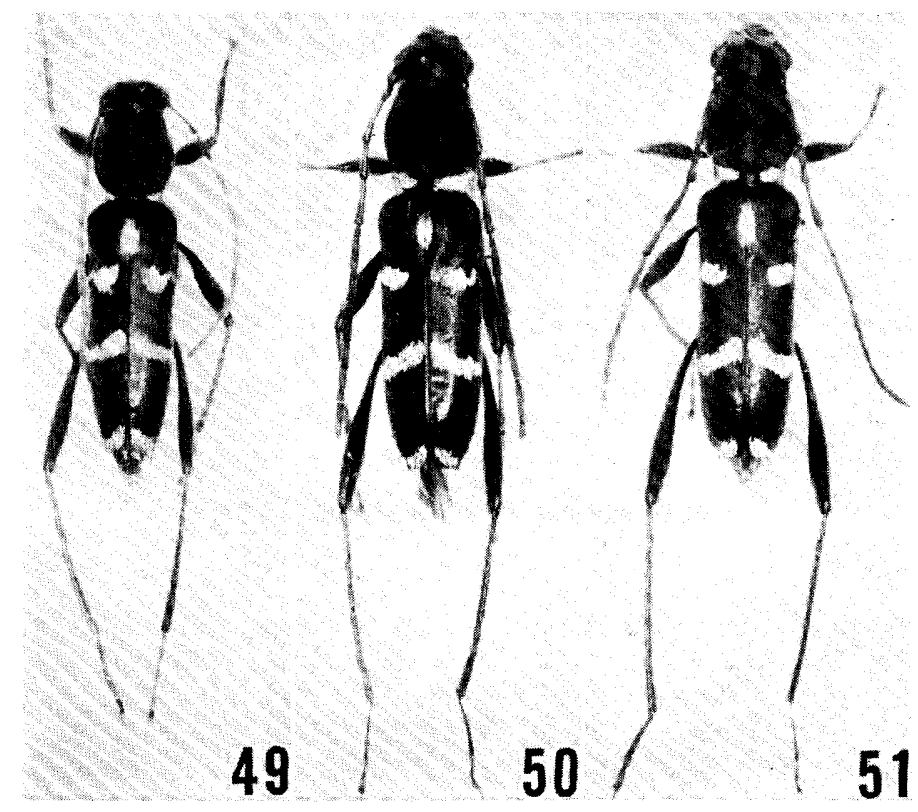

Figs. 49-51. Rhaphuma diminuta subspp. 49: diminuta from Kyushu. 50: nitens from A mamiÔshima I. 51: nitens from Okinawa I.

\section{Genus Rhaphuma Pascoe}

Rhaphuma Pascoe, 1858, Trans. Ent. Soc. London, (2)4: 240; Gahan, 1906. Fauna Brit. In- 


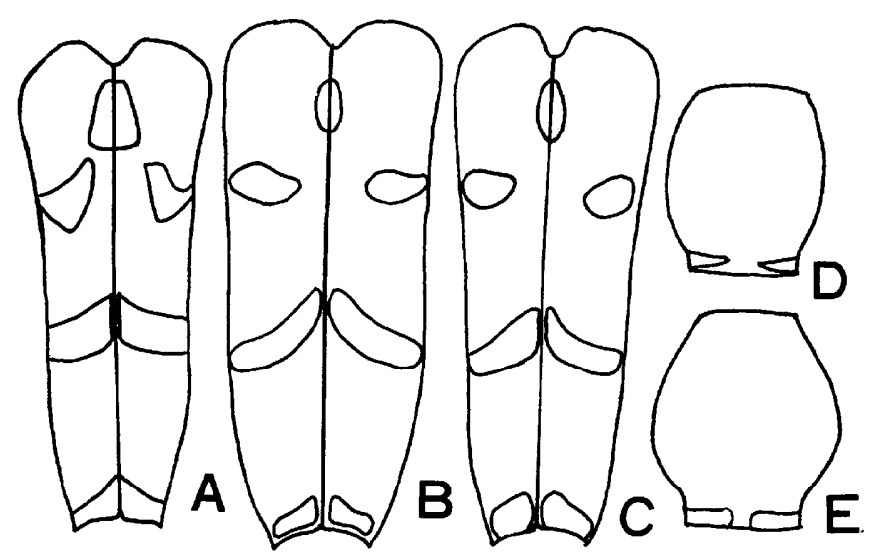

Fig. 52. Rhaphuma diminuta subspp. A-C: Elytral markings (A: diminuta from Kyushu. B: nitens from Amami-Ôshima I. C: nitens from Okinawa I.). D \& E: Pronotal markings (D: diminuta from Kyushu. E: nitens from Okinawa I.).

dia. Col., 1: 271 ; Matsushita, 1933, J. Fac. Agr. Hokkaido Imp. Univ., 34(2): 286; Mitono, 1942, Bull. School Agr. For. Taihoku Imp. Univ., 3: 79; Gressitt., 1951, Longicornia, 2: 292; Samuelson et Gressitt, 1965, Pac. Ins ,7(1): 79; Nakane, 1977, Kontyû to Shizen, $12(4): 2$.

\section{Rhaphuma diminuta nitens Hayashi}

(Figs. 50, 51 and $52 \mathrm{~B}, \mathrm{C}, \mathrm{E})$

Rhaphuma diminuta Hayashi, 1962, Ent Rev. Japan, 14(1): 12, pl. 2, fig. 9.

Rhaphuma diminuta diminuta: Kojima et al., 1965, Res. Rep. Kôchi Univ., 14, Nat. Sci.. 2(9): 86; Samuelson et Gressitt, 1965, Pac. Ins., 7(1): 79; Nakane, 1977, Kontyûu to Shizen, $12(4): 3$.

Chlorophorus diminutus diminutus: Kojima et Hayashi, 1969, Ins. Life Japan, 1: 85.

Chlorophorus diminutus nitens: Kojima et Hayashi, 1969, Ins. Life Japan, 1 : 85, p1. 26, fig. la.

Specimens examined: Okinawa I. : 1 ex., Higashimura, 5. vi. 1961, T. Takara leg. ; 1 ex., Shuri, 19. iii. 1964, T. Kakinohana leg. ; 1 ex., Kami-Mori, 25. iii. 1964, T. Shirozu leg. ; 1 ex., Mt. Yonaha, 5. iv. 1979, Y. Shôno leg.; 1 ex., same locality and data as above, H. Makihara leg. ; 3 exs., same locality and collector as above, 18. iv. 1979.

Distribution: Amami-Ôshima I. and Okinawa I.

Diagnosis: The subspecies nitens is separable from diminuta in west Japan (Figs. 49 and 52 A, D) by the following points. Pronotum with broad white band on base; elytral markings small ; body, antennae and legs shinning black.

\section{Genus Demonax Thomson}

Demonax Thomson, 1860, Classif. Ceram., p. 226; Pascoe, 1869, Trans. Ent. Soc. London, 


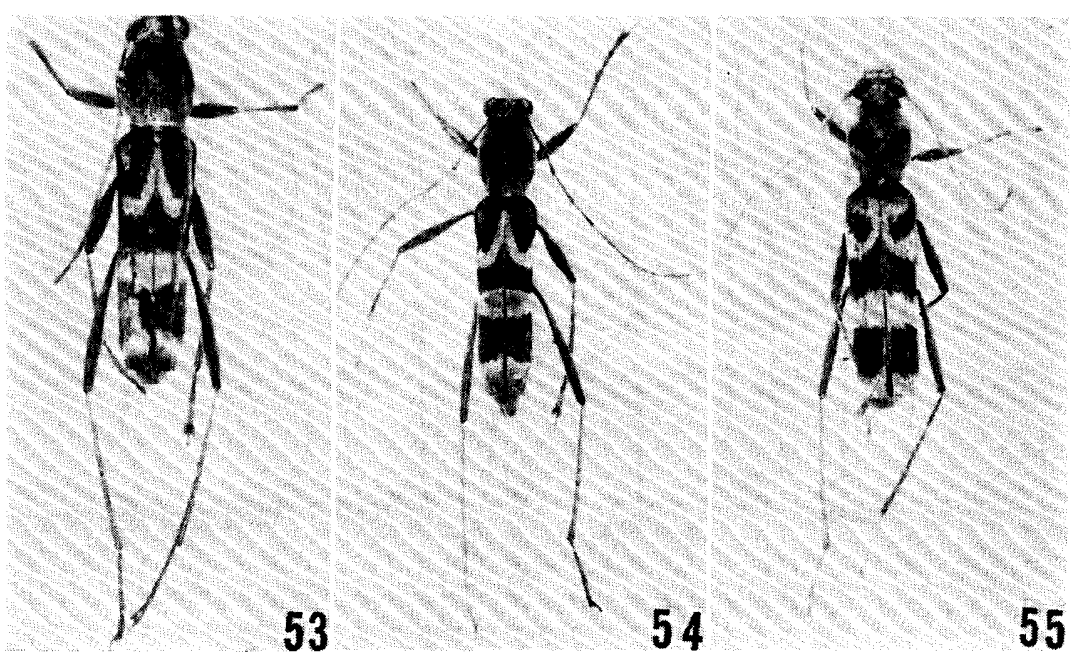

Figs. 53-55. Demonax spp. 53 : semixeniscus. 54 : masatakai. 55 : ohbayashii.

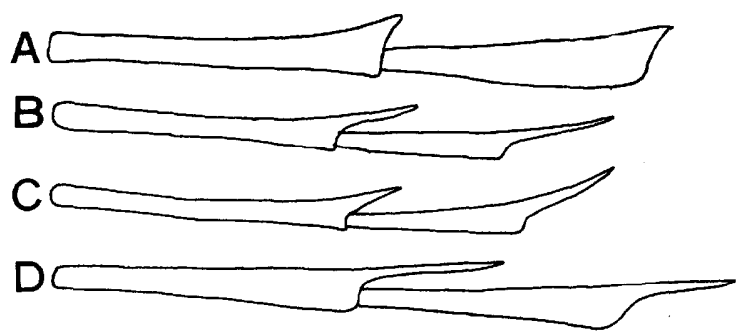

Fig. 56. Antenna1 segments 3 \& 4 of Demonax spp. A:transilis. B: semixeniscus. C: masatakai. D : ohbayashii.

(3)3: 619; Gahan, 1906, Fauna Brit. India, Col., 1: 280; Matsushita, 1933, J. Fac. Agr. Hokkaido Imp. Univ., 34(2) : 289; Mitono, 1942, Bull. School Agr. For. Taihoku Imp. Univ., 3: 95; Gressitt, 1951, Longicornia, 2: 292 ; Samuelson et Gressitt, 1965, Pac. Ins. 7(1) : 79; Kojima et Hayashi, 1969, Ins. Life Japan, 1: 83; Gressitt et Rondon, 1970 , Pac. Ins. Mon. 24: '254; Nakane, 1977, Kontyû to Shizen, 12(4): 4.

\section{KeY to the OKINAWAN species of Demona**}

1. Antennal segments $3-4$ with long spines

- Antenna1 segments 3-4 with short spines ; body length 7-12 mm

Demonax transilis Bates from Japan including Yakushima I. (Fig. 56 A)

2. Spine of antennal segment 3 shorter than that of 4; basal black marking on elytra extending to scutellum

- Spine of antennal segment 3 longer than that of 4; basal black markings on elytra extending to humeri, not to scutellum; body length 6-7 mm

Demonax ohbayashii Samuelson et Gressitt

* Some species closely related to the Okinawan species are also included. 
3. Spine of antennal segment 3 well developed; black markings on pronotum and elytra broad; body length 6-8 $\mathrm{mm}$

Demonax semixeniscus Hayashi from Amami-Ôshima I. (Figs. 53 and 56B)

- Spine of antennal segment 3 not so developed; black markings on pronotum and elytra narrow; body length $6-8 \mathrm{~mm} \ldots \ldots \ldots \ldots \ldots \ldots \ldots$ Demonax masatakai Ohbayashi

\section{Demonax masatakai Ohbayashi}

(Figs. 54 and $56 \mathrm{D})$

Demonax masatakai Ohbayashi, 1964, Bull. Japan Ent. Acad., 1(5) : 25; Kojima et Hayashi. 1969, Ins. Life Japan, $1: 84$, pl. 25, fig. 15; Nakane, 1977, Kontyû to Shizen, 12(4):5.

SPeCimens EXAmined: Ishigaki I.: 1 ex., Botanical Garden, Banna, 15. vi. 1974, H. Makihara leg. ; 1 ex., same locality and collector as above, 16. vi. 1974; 1 ex,, same locality and collector as above, 21. v. 1975; 6 exs., same locality and collector as above, 24. v. 1975. Iriomote I.: 1 ex., Funaura, 13. iv. 1979, H. Makihara leg.; 1 ex., same locality and collector as above, 14. iv. 1979.

Distribution: Ishigaki I. and Iriomote I.

Diagnosis: This species is related to D.transilis Bates and D. semixeniscus Ohbayashi, but separable from them by the key given above.

\section{Demonax ohbayashii Samuelson et Gressitt}

(Figs. 55 and 56D)

Demonax ohbayashii Samuelson et Gressitt, 1965, Pac. Ins. 7(1) : 79, fig. 4; Nakane, 1977, Kontyû to Shizen, 12(4):5; Hayashi, 1978, Ent. Rev. Japan, 31(1\& 2): 92.

Demonax masatakai: Hayashi, 1968, Ent. Rev. Japan, 21(4): 14; Kojima et Hayashi, 1969, Ins. Life Japan, 1: 84 .

Specimens examined: Ishigaki I.: 1 ex., Mt. Banna, 1. v. 1969, H. Makihara leg.; 1 ex., Botanical Garden, Banna, 15. vi. 1974, same collector as above; 1 ex., Mt. Omoto, 20. vi. 1974, same collector as above.

DistRIBUTION : Ishigaki I. and Iriomote I. 